\title{
Tachyarrhythmia in Severe Imipramine Overdose Controlled by Practolol
}

\author{
K. G. E. BROWN, H. U. S. MCMICHEN, and D. S. BRIGGS \\ From Evelina Children's Hospital of Guy's Hospital, London
}

\begin{abstract}
Brown, K. G. E., McMichen, H. U. S., and Briggs, D. S. (1972). Archives of Disease in Childhood, 47, 104. Tachyarrhythmia in severe imipramine overdose controlled by practolol. A $2 \frac{1}{2}$-year-old boy, comatose and having fits after an overdose of imipramine, suffered a respiratory and cardiac arrest from which he was successfully resuscitated. A severe tachyarrhythmia was well controlled by intravenous practolol, and it is suggested that practolol is the drug of choice in this situation.
\end{abstract}

The main features of severe imipramine overdose are coma, convulsions, respiratory arrest, and cardiac arrhythmias (Penny, 1968; Steel, O’Duffy, and Brown, 1967). The convulsions respond well to diazepam (Sacks et al., 1968). Respiratory arrest can be managed using artificial ventilation (Ramsay, 1967; Steel et al., 1967). Many deaths are due to the cardiotoxic effects of imipramine (Freeman et al., 1969; Sacks et al., 1968) which have proved difficult to manage. This report describes the successful resuscitation of a $2 \frac{1}{2}$-yearold boy who had taken a large overdose of imipramine. In particular the control of a severe tachyarrhythmia using practolol is described and the place of practolol in the management of the cardiac arrhythmias due to imipramine overdose is discussed.

\section{Case History}

A $2 \frac{1}{2}$-year-old, previously healthy, $15 \mathrm{~kg}$ boy was admitted 90 minutes after ingesting $500-600 \mathrm{mg}$ imipramine hydrochloride. The tablets were being taken by his mother as treatment for her nocturnal enuresis. 30 minutes after ingestion he had become ataxic and collapsed. He had a convulsion immediately before admission.

On examination he was unconscious, responding only to painful stimuli. He was ill kempt, with numerous skin sores and intertrigo. The pupils were fixed and dilated, and the gag reflex and limb reflexes were absent. The respiratory rate was 30 a minute and regular. The pulse rate was 100 per minute and regular. The systolic blood pressure was $90 \mathrm{mmHg}$.

Five minutes after admission he had two generalized convulsions and stopped breathing. No pulses could be felt and the heart sounds were inaudible. External

Received 28 July 1971. cardiac massage was started, a cuffed endotracheal tube was inserted and ventilation maintained manually with $100 \%$ oxygen.

A few minutes later peripheral pulses became palpable and external cardiac massage was stopped. Hand ventilation was continued. An intravenous infusion was set up. The electrocardiogram was monitored onf an oscilloscope. Gastric washouts with normal saline् were performed for 15 minutes, with recovery of only a small amount of the white powder. A further series of convulsions occurred, and each was well controlled by $2.5 \mathrm{mg}$ diazepam intravenously. Blood gases on $100 \%$ oxygen showed $p \mathrm{H} 7 \cdot 28, \mathrm{Po}_{2} 112 \mathrm{mmHg}, \mathrm{PCO}_{2} 31$ $\mathrm{mmHg}$, and bicarbonate $16 \mathrm{mEq} / 1$. Sodium bicarbonate $45 \mathrm{mEq}$ was given intravenously.

The electrocardiogram showed a supraventricular tachycardia, rate 230 per minute, with widening of the QRS complexes to $0.16 \mathrm{sec}$ (Fig. 1). Neostigmine 1 mg was given intravenously without effect. Practolol $1 \mathrm{mg}$ and then a further $2 \mathrm{mg}$ intravenously was given. This resulted over 7 minutes in a slowing of the rate to 136 per minute. The QRS complexes narrowed to $0 \cdot 10 \mathrm{sec}$ and some normally conducted sinus beats appeared. During the next $\mathbf{4 0}$ minutes the rate again increased and the QRS complexes widened to 0.24 sec giving a very abnormal electrocardiogram. Practolol $3 \mathrm{mg}$ produced a fall in rate from 220 per minute to 150 per minute and the QRS complex narrowed to 0.12 sec over 12 minutes (Fig. 1).

During this time the blood pressure rose from 80 $\mathrm{mmHg}$ systolic immediately after respiratory and cardiac arrest to $120 / 80 \mathrm{mmHg}$. The child began to breathe spontaneously at 35 per minute and, though the endotracheal tube was left in situ, hand ventilation became unnecessary. The blood gases were repeated 2 hours after admission and showed $p \mathrm{H} \mathrm{7.36}, \mathrm{Po}_{2} 60 \mathrm{mmHg}$, $\mathrm{PCO}_{2} 53 \mathrm{mmHg}$, bicarbonate $23 \mathrm{mEq} / \mathrm{l}$. Practolol was given as a continuous intravenous infusion at $1 \mathrm{mg}$ per hour and the pulse rate settled to $130-140$ per minute. 104 


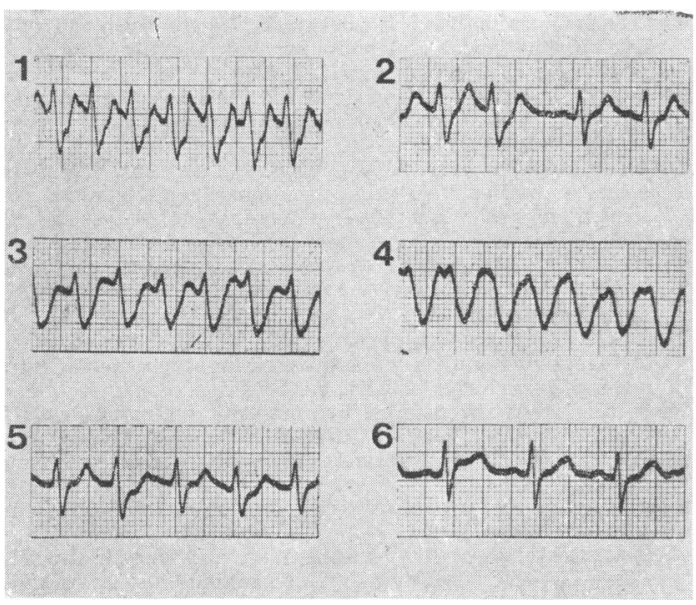

FIG. 1.-(1) Electrocardiogram before practolol; (2) 7 minutes after $3 \mathrm{mg}$ practolol intravenously; (3) 20 minutes after practolol; (4) 40 minutes after practolol; (5) 12 minutes after a further $3 \mathrm{mg}$ practolol intravenously; (6) 36 hours after admission.

Blood taken at the time of admission showed a plasma level of imipramine of $14.5 \mu \mathrm{g} / \mathrm{ml}$. Subsequent plasma levels are shown in Fig. 2.

Eight hours after admission the convulsions stopped. The arrhythmia was well controlled and the practolol was reduced to $0.5 \mathrm{mg}$ per hour. Twelve hours after admission spontaneous limb movements appeared and the endotracheal tube was removed. Three hours later he regained consciousness.

Twenty-four hours after admission the child was fully conscious. Involuntary athetoid movements of the limbs were present but passed off over the next 12 hours.

Intravenous therapy was continued to maintain normal fluid and electrolyte balance. No attempt was made at any time to force diuresis. Thirty-six hours after admission the electrocardiogram had returned to normal (Fig. 1) and practolol was stopped. Further recovery was uneventful.

An electroencephalogram and developmental assessment were normal and the child was discharged five days after admission.

\section{Discussion}

There are numerous reports of the cardiotoxic effects of imipramine overdose in man. Supraventricular tachycardia with bundle-branch block, $T$ wave and ST segment changes, atrioventricular block, bundle-branch block, hypotension, bradycardia and asystole have been described (Freeman et al., 1969; Harthorne, Marcus, and Kaye, 1963; Ramsay, 1967; Sacks et al., 1968). Animal experiments have shown an anticholinergic, atropine-like

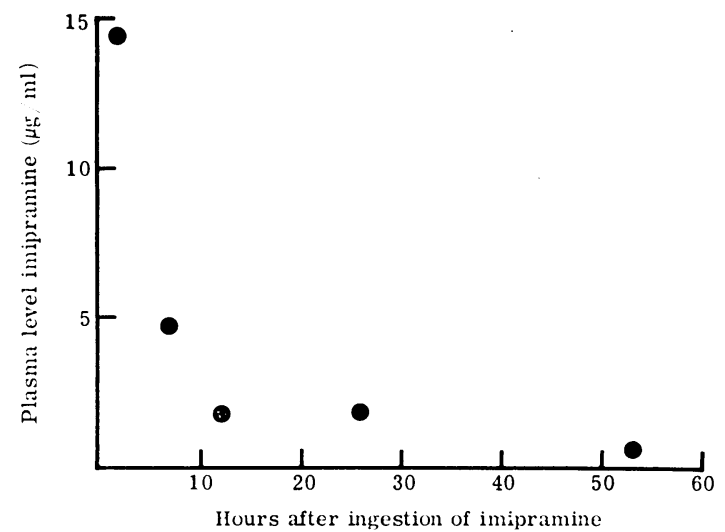

FIG. 2.-Plasma levels of imipramine.

effect and potentiation of the peripheral effects of adrenaline (Klerman and Cole, 1967; Sigg, 1959). In higher dosage there is a direct depressant action on the myocardium producing hypotension (Sigg, 1959) and on the specialized conducting tissue producing atrioventricular and bundle-branch block (Rasmussen, 1965).

The tachyarrhythmias have been treated with potassium chloride (Penny, 1968), pyridostigmine (Rasmussen, 1965), and propranolol (Freeman et al., 1969; Ramsay, 1967). The present case report describes successful control using practolol. The dose used was $6 \mathrm{mg}$, approximately one-third of an average adult dose, because the child's weight was estimated to be one-third of an average adult weight. There is little information on dosage of practolol in children, but in sinus tachycardia during anaesthesia (G. Brichard, 1971, personal communication) higher doses were required to reduce heart rate in children $(15-20 \mathrm{mg})$ than in adults $(8-10 \mathrm{mg})$.

Good control of heart rate in tachyarrhythmia has been achieved using propranolol but in the higher dosage required there is obvious myocardial depression. In Ramsay's patient $15 \mathrm{mg}$ were given intravenously, and he considers that this contributed to the depression of myocardial contractility necessitating 5 hours of continuous cardiac massage. Freeman et al., who gave $18 \mathrm{mg}$ intravenously, thought this contributed to their patient's hypotension, and suggested practolol might have been a better choice.

Practolol is a cardioselective beta-adrenergic blocker, effective in supraventricular tachyarrhythmias. It produces no clinically significant impairment of myocardial function even in patients with congestive cardiac failure and pulmonary oedema (Gibson, Balcon, and Sowton, 1968; Jewitt et al., 
1969) and produced no apparent deterioration in our patient. Myocardial depression is produced only at doses over $25 \mathrm{mg}$ (Sowton et al., 1968). This contrasts with the known myocardial depressant action of propranolol, $5 \mathrm{mg}$ intravenously producing a $20-25 \%$ decrease in cardiac output when the ventricular rate is held constant by pacing in the right ventricle (Sowton and Hamer, 1966).

Practolol may prolong atrioventricular conduction (Jewitt et al., 1969) but this action is less than propranolol. In equal dosage $(0.05 \mathrm{mg} / \mathrm{kg})$ propranolol prolongs atrioventricular nodal conduction by $17 \%$; practolol has no effect (Smithen, Balcon, and Sowton, 1971).

We feel therefore that for the treatment of tachyarrhythmias in imipramine overdose, when the function of both the myocardium and the conducting tissue may be impaired, practolol is at present the drug of choice.

No attempt was made to remove imipramine by dialysis or forced diuresis, despite the very high initial plasma level, since these measures have been shown to be ineffective (Harthorne et al., 1963). The high initial level and rapid fall (Fig. 2) reflect the quick absorption of imipramine orally, its subsequent accumulation in the tissues, and metabolism chiefly in the liver (Rasmussen, 1965).

We thank Dr. P. R. Evans for permission to report this case and for help in preparation of the paper.

\section{REFERENCES}

Brichard, G. (1971). Practolol in anaesthesia. Acta Cardiologica. (In the press.)
Freeman, J. W., Mundy, G. R., Beattie, R. R., and Ryan C. (1969). Cardiac abnormalities in poisoning with tricyclic antidepressants. British Medical fournal, 2, 610.

Gibson, D. G., Balcon, R, and Sowton, E. (1968). Clinical use of ICI 50172 as an antidysrhythmic agent in heart failure. British Medical fournal, 3, 161.

Harthorne, J. W., Marcus, A. M., and Kaye, M. (1963). Management of massive imipramine overdosage with mannitol and artificial dialysis. New England fournal of Medicine, 268, 33.

Jewitt, D. E., Mercer, C. J., Hubner, P. J., and Shillingford, J. P. (1969). Comparison of drugs used in the management of arrhythmias developing after acute myocardial infarction. British Heart fournal, 31, 794.

Klerman, G. L., and Cole, J. O. (1967). Clinical pharmacology of imipramine and related antidepressant compounds. International fournal of Psychiatry, 3, 267.

Penny, R. (1968). Imipramine hydrochloride poisoning in childhood. American Fournal of Diseases of Children, 116, 181.

Ramsay, I. D. (1967). Survival after imipramine poisoning. Lancet, 2, 1308.

Rasmussen, J. (1965). Amitryptyline and imipramine poisoning. Lancet, 2, 850.

Sacks, M. H., Bonforte, R. J., Lasser, R. P., and Dimich, I. (1968). Cardiovascular complications of imipramine intoxication. fournal of the American Medical Association, 205, 588.

Sigg, E. B. (1959). Pharmacological studies with tofranil. Canadian Psychiatric Association fournal, 4, Suppl. 75.

Smithen, C. S., Balcon, R., and Sowton, E. (1971). Use of bundle of His potentials to assess changes in atrioventricular conduction produced by a series of beta-adrenergic blocking agents. British Heart fournal, 33, 955.

Sowton, E., Balcon, R., Cross, D., and Frick, H. (1968). Haemodynamic effects of ICI 50172 in patients with ischaemic heart disease. British Medical fournal, 1, 215.

Sowton, E., and Hamer, J. (1966). Hemodynamic changes after beta adrenergic blockade. American fournal of Cardiology, 18, 317.

Steel, C. M., O'Duffy, J., and Brown, S. S. (1967). Clinical effects $\bigcirc$ and treatment of imipramine and amitryptyline poisoning in children. British Medical fournal, 3, 663.

Correspondence to Dr. K. G. E. Brown, Evelina Children's Hospital, Southwark Bridge Rọad, London S.E.1. 